\title{
THE ACUTE EFFECT OF RUNNING EXERCISE ON LIVER ABCA1 GENE EXPRESSION IN MALE WISTAR RATS
}

\author{
Seyed Morteza Tayebi ${ }^{1}$, tayebism@atu.ac.ir, ORCID: 0000-0003-0459-4443, \\ Mitra Khademosharie ${ }^{2}$, m_khadem_un@yahoo.com, ORCID: 0000-0003-4422-8093, \\ Tayebe Amiri Parsa ${ }^{3}$, amiritayebe@yahoo.com, ORCID: 0000-0002-5032-7816, \\ Mehdi Abaszadegan ${ }^{4}$, m.abaszadegan@gmail.com, ORCID: 0000-0001-6051-5565, \\ Ayoub Saeidi ${ }^{5}$, saeidi_as68@yahoo.com, ORCID ID: 0000-0003-2458-6256, \\ A.V. Nenasheva ${ }^{6}$, nenashevaav@susu.ru, ORCID: 0000-0003-0092-2948 \\ ${ }^{1}$ Allameh Tabataba'i University, Tehran, Iran, \\ ${ }^{2}$ Razi University, Kermanshah, Iran, \\ ${ }^{3}$ Hakim Sabzevari University, Sabzevar, Iran, \\ ${ }^{4}$ Payame Noor University, Maku, Iran, \\ ${ }^{5}$ University of Mazandaran, Babolsar, Mazandaran, Iran, \\ ${ }^{6}$ South Ural State University, Chelyabinsk, Russian Federation
}

\begin{abstract}
Objectives. ATP-binding cassette transporters transfer a variety of substrates across the lipid bilayers in an energy-dependent manner. ABCA1 is a member of this family, which plays a crucial role in plasma HDL-C metabolism. On the other hand, the short-term effects of exercise training are less studied. The aim of this study was the effects of a single bout of exercise on liver ABCA1 gene expression in the male Wistar rats. Methods. Twenty four male Wistar rats were housed in a standard environment and randomly divided into two Control $(\mathrm{n}=12)$ and Experimental $(\mathrm{n}=12)$ groups. The exercise included running on a treadmill for $120 \mathrm{~min}(18 \mathrm{~m} / \mathrm{min})$. Immediately, 2 and 24 hours after exercise, rats were anesthetized, and samples were taken from the adipose tissue and liver. Liver ABCA1 was assessed by RT-PCR. Results. The results showed that liver ABCA1 gene expression had significant elevation immediately, 2 and 24 hours after exercise $(\mathrm{p}<0.05)$. Conclusion. The findings of this study proved that acute exercise can increase liver ABCA1 gene expression.
\end{abstract}

Keywords: ABCA1, Gene Expression, Exercise, Liver, Adipose Tissue, Wistar Rats.

\section{INTRODUCTION}

Cardiovascular diseases are the leading cause of mortality throughout the world and have gained the first rank among chronic diseases (disease burden in the world). In Iran, after mental illness, most statistics are related to cardiovascular disease [12]. Blood lipid profile is one of the health markers and especially of cardiovascular system health. So, high level of cholesterol, LDL, triglyceride, and low level of HDL is associated with increased CVD risk factors [19, 20]. Many efforts have been made to identify the protective mechanisms of HDL in cardiovascular complications [9]. It has been proposed that reverse cholesterol transport is a possible mechanism. It includes the process of collecting excess cholesterol from peripheral tissues such as arteries macrophages and returning them to the liver, which accompanies with HDL deformation [18]. The first phase of reverse cholesterol transport is related to extracellular receptors, namely Apo A-I that mediated by $\mathrm{ABCA} 1$ transporter and cause to form the pre-beta HDL particles. ABCA1 is expressed in different tissues, but its role in these tissues is uncertain. Given that the liver is the major source of HDL [16], the study of ABCA1 in this tissue can provide valuable information [2].

Various factors can affect ABCA1 gene expression, and one of them is physical activities and exercise. Also, many studies have surveyed the effect of various exercise training on the HDL, and an increased rate and composition of HDL have been confirmed [3]. However, few studies have been conducted on other stages of reverse cholesterol transport. For example, only one study has been reported an increased removal of cholesterol from cells in trained individuals [1]. Another study has reported an increase in apolipoprotein A-I as a result of exercise. The training protocol was not performed, and participants were classified into training and without training groups via a questionnaire [13]. Few studies have been conducted on ABCA1. One study showed that 12-week aerobic training resulted in the upregulation of ABCA1 in rat intestine [11]. The other study concluded that Treadmill exercise training enhanced $\mathrm{ABCA} 1$ gene expression in rat liver [5]. Also, it has been demonstrated that a 6-week 


\section{Физиология}

endurance training overexpressed liver ABCA1 in rats [10] and showed that a single session of circuit-resistance exercise affected human peripheral blood lymphocyte ABCA1 expression in female students [6]. The other study surveyed the effect of a high-intensity treadmill running program on rat heart tissue ABCA1 and PPAR- $\alpha$ genes expression [4].

It is clear from the review studies that despite the importance of the process of reverse cholesterol transport and the role of ABCA1 in the prevention of cardiovascular disease, little training study has been conducted in this area, especially with the short-term and single-session protocol. So, the present study investigates the effect of a single bout of exercise on liver $\mathrm{ABCA} 1$ in the rat.

\section{MATERIAL AND METHODS}

Animals. Twenty four male Wistar rats (weight $338 \pm 31 \mathrm{~g}$ ) were acquired from Pasteur's Institute (Tehran, Iran). They were kept in standard conditions (temperature: $22 \pm 2{ }^{\circ} \mathrm{C}$, lightdark cycle: $12: 12 \mathrm{~h}$, relative humidity: $50 \%$ and access to water and food). After a week of familiarity to a Lab space and manipulations by the researcher, the rats were randomly divided into the experiment $(\mathrm{n}=12)$ and control $(\mathrm{n}=12)$ groups with the same weight. The ethics committee of Urmia University approved the study (UMSU.REC.IR.1394.451).

Exercise Protocol. The training involved running exercise on a rodent treadmill. After a few training sessions to make rats familiar with the lab and observe the overload principle, we conducted an experiment where the rats ran on a treadmill at $18 \mathrm{~m} / \mathrm{min}$ for 120 minutes. The control group also walked on a treadmill at $8 \mathrm{~m} / \mathrm{min}$ for $10 \mathrm{~min}$, three times during two weeks of familiarity.

Blood and Tissue Sampling. Food was removed from cages $4 \mathrm{~h}$ before training to take the blood samples in a relatively fasting mode. Immediately, 2 and 24 hours after the last training session, 8 rats (4 experimental and 4 control) were anesthetized with intraperitoneal administration of pentobarbital sodium $(6 \mathrm{mg} / 100 \mathrm{~g}$ body weight) and sampling of blood, the adipose tissue and liver were collected. Blood sampling was done by perforating heart and syringe. The adipose tissue and liver were excised, transported to RNAase free and DNAase microtubes and frozen in liquid nitrogen. Blood samples were centrifuged in EDTA contained falcon tubes and stored at $-80{ }^{\circ} \mathrm{C}$ together with tissue samples.
Liver ABCA1 Gene Expression. Semiquantitative RT-PCR was done for ABCA1 gene expression in the Liver tissue. For this purpose, $20 \mathrm{mg}$ of tissues were separated and served for RNA extraction reaction. RNA refining was done using a kit of MN firm (Germany). Firstly, tissues were autolyzed by adding $350 \mu \mathrm{RA} 1$ and $3 / 5 \mu \mathrm{l}$ mercaptan solution. Then, this solution with bufferlyse was added to a column (containing red ring) and centrifuged at 11000 cycles for a minute. The solution passed from the column was collected in a microtube. Then the condition for pasting RNA became suitable by adding 350 microlitres $70 \%$ alcohol, and, in this phase, the composition was mixed with a pipet. Above homogenized solution was added to a refined RNA column (blue ring) and centrifuged at 11000 cycles for 30 seconds. Then, $350 \mu \mathrm{l}$ of MDB buffer were added and centrifuged at 11000 cycles for a minute. Using $95 \mu 1$ of DNase solution and 15-minute incubation, DNAs accompanied by RNA, which linked to membrane, was removed. After, $200 \mu 1$ of RA2 solution and following $600 \mu \mathrm{l}$ of RA3 were added to the column and centrifuged at 11000 cycles for 30 seconds. In the next phase, $250 \mu \mathrm{l}$ of RA3 were added and centrifuged at 11000 cycles for 2 minutes. $60 \mu \mathrm{l}$ of RNase free water were added to the column and centrifuged at 11000 cycles for a minute and stored at $-70{ }^{\circ} \mathrm{C}$. The quantitative rate of RNA extraction with its Optical density (OD) at $260 \mathrm{~nm}$ was determined in biophotometer. To make cDNA in a tube without RNase, 100-400 ng total RNA and $0 / 5 \mu \mathrm{g}$ oligo primer dT were added to it. The last volume reaches $11 \mu \mathrm{l}$ by aqua pure without RNase. The collection was incubated at $70{ }^{\circ} \mathrm{C}$ for 5 minutes and then was cooled immediately on ice. (5X)RT buffer $4 \mu$, dNTP mix (10mM) $2 \mu \mathrm{l}$, and (RNasin) Ribonuclease inhibitor 20 unit were added and reached to the last volume of $19 \mu \mathrm{l}$ by aqua pure without RNase and incubated for 5 minutes at $37^{\circ} \mathrm{C}$. Then 200 units of reverse transcriptase enzyme (M-Mul-V) were added and incubated for an hour at $42{ }^{\circ} \mathrm{C}$. In the next phase, it was exposed to $70{ }^{\circ} \mathrm{C}$ for 10 minutes which inactivated the enzyme. Then immediately transported to the ice pot. A cDNA product was stored at $-70{ }^{\circ} \mathrm{C}$. Using the aboveprepared cDNA sample, PCR was conducted according to the following protocol. In this process, beta-actin was used as an intrinsic control, and a PCR reaction was conducted with beta-actin primers for every sample. 
Сейед Мортеза Тайеби, Митра Хадемошари, Тайебе Амири Парса и др.

FORWARD PRIMER:

TGACACCAAAACCCTCATCA

REVERSE PRIMER:

AGCCCGGGAATGAAGTCCA

Beta actin (in leptin RT-PCR)

BA-for:

(5'-AGTAGGCTTTGTGGTTGATG-3')

BA-rev:

(5'-CTGTCAGGAAAGGAGAAATC-3')

PCR product length: $429 \mathrm{bp}$

For evaluating PCR results, we used the electrophoresis of a PCR product on Agarose gel and UVtech software. ANOVA test with repeated measurements was used to evaluate the effect of training on $\mathrm{ABCA}_{1}$ gene expression $(\mathrm{p}<0.05)$, and all statistical analyses were conducted in SPSS (version 21).

\section{RESULTS}

The results showed that exercise training increases liver ABCA1 gene expression immediately, 2 and $24 \mathrm{~h}$ after exercise.

The results of the liver ABCA1 gene expression has been shown in figure 1 . The expression of this gene was measured in comparison with the expression of the internal control gene (betaactin). Letter $\mathrm{C}$ and $\mathrm{T}$ on the bands indicate the control and exercise group, respectively. In Time 0 , the bands from left to right are $\mathrm{C} 1$ to $\mathrm{C} 4$ for control and $\mathrm{T} 1$ to $\mathrm{T} 4$ for the trained rats (fig. 1a). In Time 2, C5 to $\mathrm{C} 8$ and $\mathrm{T} 5$ to $\mathrm{T} 8$ include

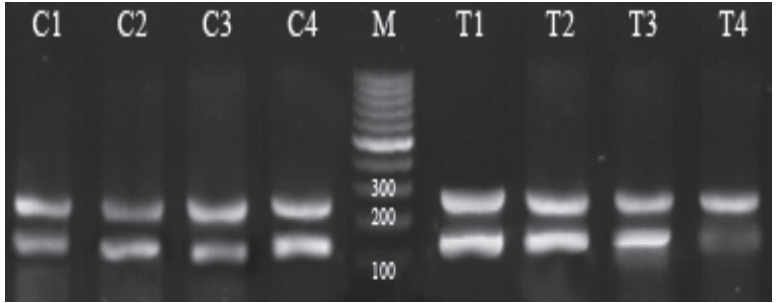

a)
Кратковременный эффект беговых упражнений на экспрессию гена печени АBCA1...

the control and experimental groups, respectively (fig. 1b). In Time 24, C9 to C 12 is the control and T9 to $\mathrm{T} 12$ is the experimental group (fig. $1 \mathrm{c}$ ). $M$ is also the marker of molecular weight. The weight of the important bands has been shown in the fig. Accordingly, the results of this research on the gene expression of ABCA1 in the liver showed a significant increase in the experimental group compared with the control group immediately, 2 and 24 hours after exercise $(\mathrm{p}<0.05)$ (fig. 2).

\section{DISCUSSION}

The main finding of the present study was higher liver ABCA1 gene expression immediately, 2 and $24 \mathrm{~h}$ after exercise. To our knowledge, this is the first study that investigates the genetic variations in tissue using such an exercise protocol. In the present study, the increase of ABCA1 expression was in line with the results of previously reported findings on different subjects with different training protocols $[5,8,10]$.

Ghanbari-Niaki investigated the effect of a 12-week endurance exercise (intensity: $25 \mathrm{~m} / \mathrm{min}$, duration: $60 \mathrm{~min} / \mathrm{session}$, and five days a week), that resulted in ABCA1gene expression increase in the rat's heart. Plasma apo-A and pre- $\beta$-HDL concentrations were significantly increased [7]. Also, it has been shown that eight weeks of lowintensity exercise (walking) significantly upregulated ATP-binding cassette transporters A1 (ABCA1) [15].

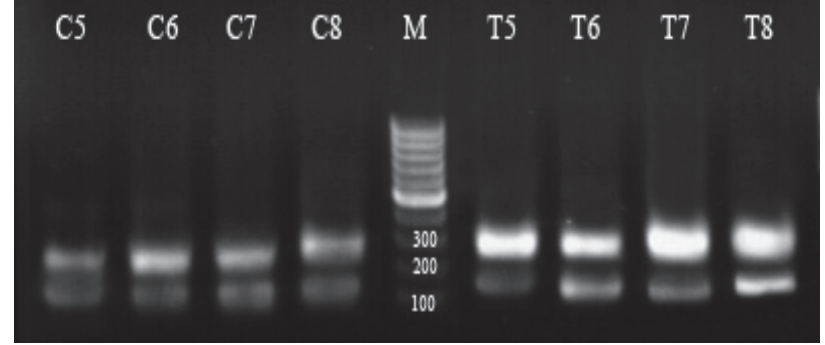

b)

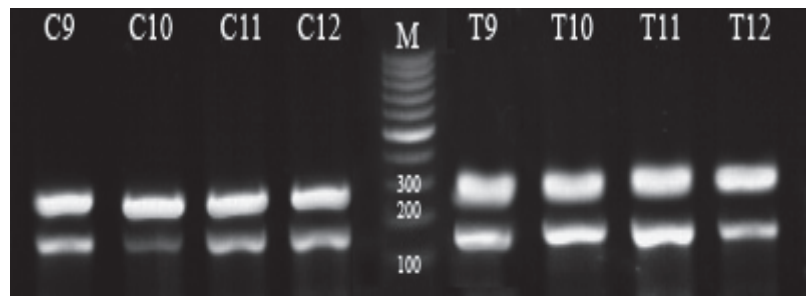

c)

Fig. 1. Semi-quantitative RT-PCT of liver' ABCA1 and $\beta$-actin mRNA expression in control and trained male rats and ABCA1/ B-actin mRNA expression ratio: a - time $0 /$ immediately after exercise, b - time 2/2 hours after exercise, c - time 24/24 hours after exercise 


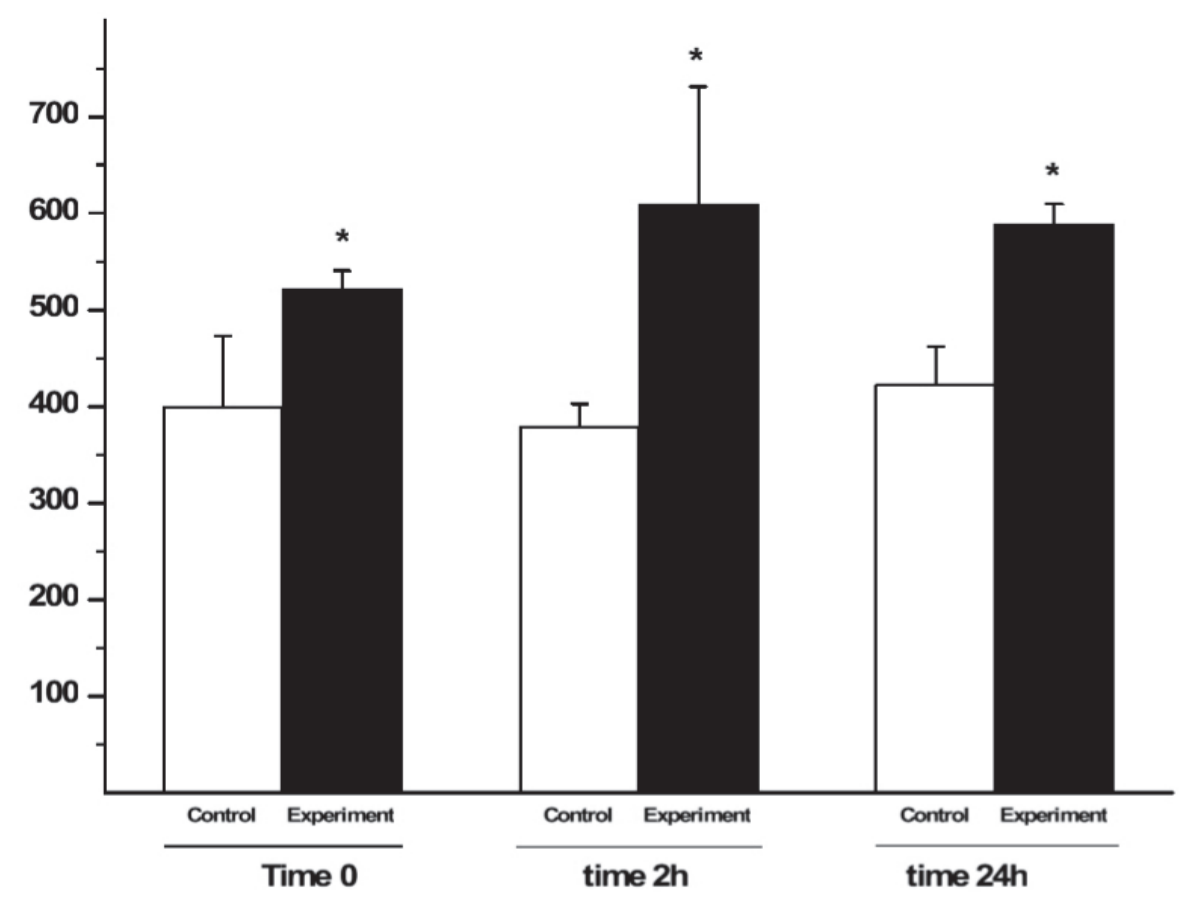

Fig 2. The changes in the gene expression of ABCA1 in the liver immediately (Time 0 ), 2 hours (Time 2), and 24 hours (Time 24) after exercise

Hoang et al. reported that participants with high physical activity had higher levels of ABCA1 expression in leukocytes [8]. Ghanbari-Niaki et al. reported that a single session of circuit-resistance exercise (CRE) increased peripheral blood lymphocyte ABCA1 expression and plasma HDL-C level in human [6]. The mechanism of how circuit-resistance exercise increases lymphocyte $\mathrm{ABCA} 1$ expression is unclear. A higher $\mathrm{ABCA} 1$ expression might be attributed to an exerciseinduced lymphocytosis, particularly after a resistance exercise which has been reported by previous studies [17]. According to Simonson and Jackson, a resistance exercise ( 8 exercises, 3 sets, and $8-10$ repetitions at $75 \%$ of $1 \mathrm{RM}$ ) increased all leukocyte subpopulations which was accompanied by a significant increase in lymphocytes counts. They suggested that this leukocytosis was due to an increase in circulating lymphocytes [17]. Rashidlamir et al. reported that two months of cardiac rehabilitation training elevated ABCA1 expression in the lymphocytes of patients undergoing coronary artery bypass graft operation [14].

$\mathrm{ABCA} 1$ is a cell membrane transporter that facilitates the delivery of phospholipids from cell membranes to lipid-poor apoA-1 with the formation of discoidal apoA-I- containing HDL, and it plays a pivotal role in forming plasma HDL. The mechanism(s) by which the exercise can influence liver ABCA1 gene expression is (are) poorly understood. However, several possible mechanisms could be considered. It has been suggested that the modulating effect of fatty acids (FA) is mediated by peroxisome proliferatoractivated receptors (PPARs), and it is also well known that PPAR is a nuclear receptor like liver $\mathrm{X}$ receptor (LXR) and retinoid $\mathrm{X}$ receptor (RXR) that regulates the expression of genes controlling lipid and glucose metabolism [13].

Contrary to this research, Ghanbari-Niaki et al. showed that a high-intensity running program ( $34 \mathrm{~m} / \mathrm{min}$ ( $0 \%$ grade), $60 \mathrm{~min} /$ day, 5 days/week) on a motor-driven treadmill for eight weeks did not significantly change heart ABCA1 and PPAR $\alpha$ genes expression [4]. One of the reasons for this difference may be related to the duration and intensity of the exercise training in these studies.

Increased ABCA1 expression after $24 \mathrm{~h}$ shows that the positive effects of training sustain even after $24 \mathrm{~h}$. Increased ABCA1, which is the main responsible for reverse cholesterol transport and phospholipids to apo A-I, indicates that more apoA-I is lipidated [10]. This can explain the part of the positive effect of training through affecting blood lipids. The cause of increased ABCA1 as a result of training can indicate increased LCAT and pre-b-HDL, which have occurred in response to training [10].

Finally, it can be concluded that the increase of ABCA1 gene expression in the liver subse- 
quent to one session of long term aerobic exercise supports the regulating and coordinating role of this factor after exercise training and show the positive effects of acute exercise on fat metabolism. Of course, in this study, the lipid profile of plasma was not studied due to some limitations; higher training intensity with more sample number can inspire a more precise insight in this respect.
Acknowledgment. We would like to appreciate the department of biotechnology in the school of medicine of Tarbiat Moddares University in Tehran for its sincere cooperation; particularly the authors wish to thank Dr. Fatemeh Rahbari Zadeh for her help in conducting biochemical experiments and RT-PCR. Dr. Mahdi Jabbari is appreciated for statistical counseling.

\section{References}

1. Brites F., Verona J., De Geitere C., Fruchart J.-C., Castro G., Wikinski R. Enhanced Cholesterol Efflux Promotion in Well-Trained Soccer Players. Metabolism, 2004, vol. 53 (10), pp. 1262-1267. DOI: 10.1016/j.metabol.2004.05.002

2. Brunham L.R., Kruit J.K., Iqbal J., Fievet C., Timmins J.M., Pape T.D. et al. Intestinal ABCA1 Directly Contributes to HDL Biogenesis in Vivo. J Clin Invest, 2006, vol. 116 (4), pp. 1052-1062. DOI: 10.1172/JCI27352

3. Durstine J.L., Grandjean P.W., Davis P.G., Ferguson M.A., Alderson N.L., DuBose K.D. Blood Lipid and Lipoprotein Adaptations to Exercise: a Quantitative Analysis. Sports Medicine (Auckland, NZ), 2001, vol. 31 (15), pp. 1033-1062. DOI: 10.2165/00007256-200131150-00002

4. Ghanbari-Niaki A., Ghanbari-Abarghooi S., Rahbarizadeh F., Zare-Kookandeh N., Gholizadeh M., Roudbari F. et al. Heart ABCA1 and PPAR- $\alpha$ Genes Expression Responses in Male Rats: Effects of High Intensity Treadmill Running Training and Aqueous Extraction of Black Crataegus-Pentaegyna. Research in Cardiovascular Medicine, 2013, vol. 2 (4), pp. 153-159. DOI: 10.5812/cardiovascmed. 13892

5. Ghanbari-Niaki A., Khabazian B.M., Hossaini-Kakhak S.A., Rahbarizadeh F., Hedayati M. Treadmill Exercise Enhances ABCA1 Expression in Rat Liver. Biochemical and Biophysical Research Communications, 2007, vol. 361 (4), pp. 841-846. DOI: 10.1016/j.bbrc.2007.07.100

6. Ghanbari-Niaki A., Saghebjoo M., Hedayati M. A Single Session of Circuit-Resistance Exercise Effects on Human Peripheral Blood Lymphocyte ABCA1 Expression and Plasma HDL-C Level. Regulatory Peptides, 2011, vol. 166 (1), pp. 42-47. DOI: 10.1016/j.regpep.2010.08.001

7. Ghanbari-Niaki A. Treadmill Exercise Training Enhances ATP-Binding Cassette Protein-A1 (ABCA1) Expression in Male Rats' Heart and Gastrocnemius Muscles. International Journal of Endocrinology and Metabolism, 2010, vol. 8 (4), pp. 206-210.

8. Hoang A., Tefft C., Duffy S.J., Formosa M., Henstridge D.C., Kingwell B.A. et al. ABCA1 Expression in Humans is Associated with Physical Activity and Alcohol Consumption. Atherosclerosis, 2008, vol. 197 (1), pp. 197-203. DOI: 10.1016/j.atherosclerosis.2007.03.017

9. Hosseinzadeh M., Rashid Lamir A., Hejazi S.M. Are Heart Muscle Irisin Levels and FNDC5 Gene Expression Regulated by Endurance and Resistance Exercises? Annals of Applied Sport Science, 2018, vol. 6 (1), pp. 21-28. DOI: 10.29252/aassjournal.6.1.21

10. Khabazian B.M., Ghanbari Niaki A., Rahbarizadeh F., Hoseini Kakhak A., Jabari Noghabi M. The Effect of 6 Weeks of Endurance Training on the Expression of Hepatic ABCA1 in Male Wistar Rats. World Journal of Sport Sciences, 2008, vol. 1 (1), pp. 1-7.

11. Khabazian B.M., Ghanbari-Niaki A., Safarzadeh-Golpordesari Ar., Ebrahimi M., Rahbarizadeh F., Abednazari H. Endurance Training Enhances ABCA1 Expression in Rat Small Intestine. European Journal of Applied Physiology, 2009, vol. 107 (3), pp. 351-358. DOI: 10.1007/s00421-009-1133-3

12. Naghavi M., Abolhasani F., Moradi M., Jafari N., Shoaee S.H., Vaseghi S. Burden of Diseases in Iran. Tehran, Iran: Iran Ministry of Health, 2006.

13. Olchawa B., Kingwell B.A., Hoang A., Schneider L., Miyazaki O., Nestel P. et al. Physical Fitness and Reverse Cholesterol Transport. Arterioscler Thromb Vasc Biol, 2004, vol. 24 (6), pp. 1087-1091. DOI: 10.1161/01.ATV.0000128124.72935.0f

14. Rashidlamir A., Dastani M., Saadatnia A., Bassami M.R. Effect of Cardiac Rehabilitation Training on ABCA1 Expression in Lymphocytes of Patients Undergoing Coronary Artery Bypass Graft Operation. Zahedan Journal of Research in Medical Sciences, 2018, vol. 20 (6), e11277. DOI: 10.5812/zjrms.11277

15. Rashidlamir A., Ghanbari-Niaki A., Saadatnia A. The Effect of Eight Weeks of Wrestling and Wrestling Technique Based Circuit Trainingon Lymphocyte ABCA1 Gene Expression and Plasma Apolipoprotein A-I. World Journal of Sport Sciences, 2011, vol.4 (2), pp. 144-150. DOI: 10.1080/21615667.2011.10878931 


\title{
Физиология
}

16. Rashidlamir A., Hoseinzadeh M., Zeiaddini Dashtkhaki L. The Effects of Resistance and Endurance Training on the Liver Tissue FNDC5 mRNA Gene Expression in Male Rats. Annals of Applied Sport Science, 2017, vol. 5 (2), pp. 51-60. DOI: 10.18869/acadpub.aassjournal.5.2.51

17. Simonson S.R., Jackson C.G. Leukocytosis Occurs in Response to Resistance Exercise in Men. Journal of Strength and Conditioning Research, 2004, vol. 18 (2), pp. 266-271. DOI: 10.1519/ 00124278-200405000-00011

18. Yancey P.G., Bortnick A.E., Kellner-Weibel G., de la Llera-Moya M., Phillips M.C., Rothblat G.H. Importance of Different Pathways of Cellular Cholesterol Efflux. Arterioscler Thromb Vasc Biol, 2003, vol. 23 (5), pp. 712-719. DOI: 10.1161/01.ATV.0000057572.97137.DD

19. Zamani M., Peeri M. The Effect of Body Part-Dependent Resistance Training on Lipid Profiles and Hormonal Levels in Young Males. Annals of Applied Sport Science, 2017, vol. 5 (1), pp. 51-58. DOI: 10.18869/acadpub.aassjournal.5.1.51

20. Zamani M., Peeri M. The Effects of Eight Weeks Upper Body and Lower Body Resistance Training on Plasma Adiponectin and Leptin Levels in Young Men. Annals of Applied Sport Science, 2017, vol. 5 (1), pp. 1-6. DOI: 10.18869/acadpub.aassjournal.5.1.1

Received 15 May 2019

\section{КРАТКОВРЕМЕННЫЙ ЭФФЕКТ БЕГОВЫХ УПРАЖНЕНИЙ НА ЭКСПРЕССИЮ ГЕНА ПЕЧЕНИ АВСА1 У САМЦОВ КРЫС ПОРОДЫ WISTAR}

\author{
Сейед Мортеза Тайеби ${ }^{1}$, Митра Хадемошари ${ }^{2}$, Тайебе Амири Парса ${ }^{3}$, \\ Мехди Абасзадеган ${ }^{4}$, Аюб Саеди ${ }^{5}$, А.В. Ненашева ${ }^{6}$ \\ ${ }^{1}$ Университет им. Алламе Табатабаи, г. Тегеран, Иран, \\ ${ }^{2}$ Университет Рази, г. Керманшах, Иран, \\ ${ }^{3}$ Университет им. Хакима Сабзевари, г. Сабзевар, Иран, \\ ${ }^{4}$ Университет Пайаме Нур, г. Маку, Иран, \\ ${ }^{5}$ Университет Мазандарана, г. Баболсар, провинция Мазандаран, Иран, \\ ${ }^{6}$ Южно-Уральский государственный университет, г. Челябинск, Россия
}

Цель. АТФ-связывающие кассетные транспортеры переносят различные субстраты через липидный двуслой энергетически-зависимым способом. Ген АВСА1 является членом этого семейства, которое играет первостепенную роль в метаболизме липопротеинов высокой плотности, находящихся в плазме. При этом краткосрочный эффект тренировочных нагрузок на экспрессию данного гена до сих пор остается малоизученным. Цель данного исследования - выявить, какое влияние оказывает однократное выполнение упражнения на экспрессию гена печени ABCA1 у самцов крыс породы Wistar. Методы. 24 самца крысы породы Wistar были размещены в стандартных условиях и разделены случайным образом на две контрольные $(\mathrm{n}=12)$ и экспериментальные $(\mathrm{n}=12)$ группы. Тренировочная нагрузка включала в себя бег на специальном тредмиле в течение 120 минут (18 м/мин). Для взятия образцов из печени и жировой ткани крысы были анестезированы сразу, через два часа и через двадцать четыре часа после выполнения упражнения. Ген АВСА1 был исследован методом ПЦР с обратной реакцией. Результаты. Результаты исследования показали, что экспрессия гена печени ABCA1 значительно возросла сразу, через два часа и через двадцать четыре часа после выполнения упражнений $(\mathrm{p}<0,05)$. Заключение. Полученные результаты подтвердили, что тяжелая физическая нагрузка может повысить экспрессию гена печени АBCA1.

Ключевые слова: АВСА1, экспрессия гена, упражнение, печень, жировая ткань, крысы nopodbl Wistar. 
Благодарность. Выражаем благодарность коллективу кафедры биотехнологии медицинского факультета Университета Тарбиат Моддарес в г. Тегеране за сотрудничество, в частности доктору Фатеме Рахбари Заде за помощь в проведении биохимических экспериментов и использовании метода ПЦР с обратной реакцией, а также доктору Махди Джаббари за ценные консультации в области статистики.

Сейед Мортеза Тайеби, центр фундаментальных исследований физиологии здоровья и физической активности, кафедра физиологии упражнений, факультет спортивных наук, Университет им. Алламе Табатабаи. 1485743411, Олимпийская деревня, Западный вход спорткомплекса Азади, г. Тегеран, Иран. E-mail: tayebism@atu.ac.ir, ORCID: 0000-0003-0459-4443.

Митра Хадемошари, кафедра физиологии упражнений, факультет спортивных наук, Университет Рази. 6714414971, ул. Данешгах, Так-е Бостан, г. Керманшах, Иран. E-mail: m_khadem_un@ yahoo.com, ORCID: 0000-0003-4422-8093.

Тайебе Амири Парса, кафедра физиологии упражнений, факультет спортивных наук, Университет им. Хакима Сабзевари. 9617976487, Тоид Шахр, г. Сабзевар, Иран. E-mail: amiritayebe@ yahoo.com, ORCID: 0000-0002-5032-7816.

Мехди Абасзадеган, кафедра физиологии упражнений, Университет Пайаме Нур. 5877138477 , ул. Валиаср, г. Маку, Иран. E-mail: m.abaszadegan@gmail.com. ORCID: 0000-0001-6051-5565.

Аюб Саеди, отделение биохимии упражнений, факультет физической культуры и спортивных наук, Университет Мазандарана. 4741613534, ул. Шахид Бехешти, г. Баболсар, провинция Мазандаран, Иран. E-mail: saeidi_as68@yahoo.com, ORCID: 0000-0003-2458-6256.

Ненашева Анна Валерьевна, доктор биологических наук, заведующий кафедрой теории и методики физической культуры и спорта Института спорта, туризма и сервиса, Южно-Уральский государственный университет. 454080, г. Челябинск, проспект Ленина, 76. E-mail: nenashevaav@ susu.ru, ORCID: 0000-0003-0092-2948.

Поступила в редакцию 15 мая 2019 г.

\section{ОБРАЗЕЦ ЦИТИРОВАНИЯ}

The Acute Effect of Running Exercise on Liver ABCA1 Gene Expression in Male Wistar Rats / Seyed Morteza Tayebi, Mitra Khademosharie, Tayebe Amiri Parsa et al. // Человек. Спорт. Медицина. - 2019. T. 19, № S1. - C. 43-49. DOI: 10.14529/hsm19s106

\section{FOR CITATION}

Seyed Morteza Tayebi, Mitra Khademosharie, Tayebe Amiri Parsa, Mehdi Abaszadegan, Ayoub Saeidi, Nenasheva A.V. The Acute Effect of Running Exercise on Liver ABCA1 Gene Expression in Male Wistar Rats. Human. Sport. Medicine, 2019, vol. 19, no. S1, pp. 43-49. DOI: $10.14529 / \mathrm{hsm} 19 \mathrm{~s} 106$ 